\title{
DESIGN OF A DESIGNATION FOR EMERGENCY MEDiCAL SERVICES AT DEPARTMENT STORES
}

\author{
Martin Dzermansky, Ondrej Kostka \& Marketa Habrova
}
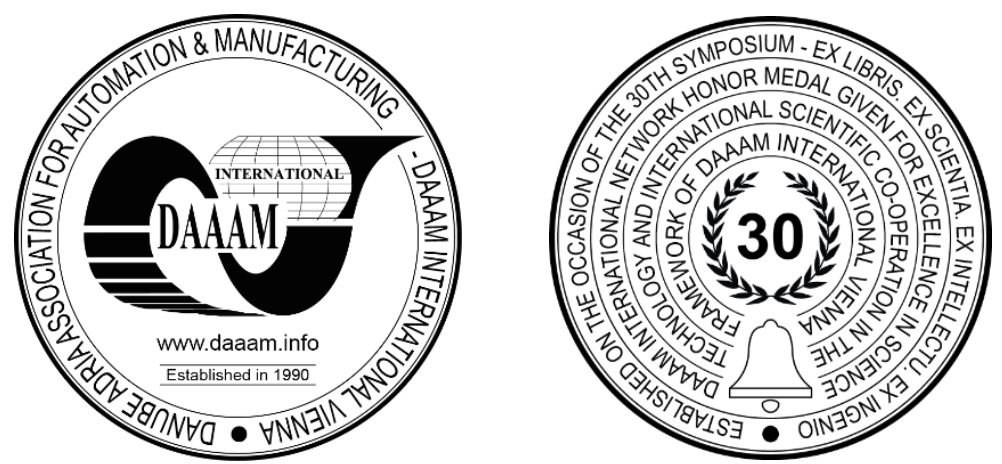

This Publication has to be referred as: Dzermansky, M[artin]; Kostka, O[ndrej] \& Habrova, M[arketa] (2021). Design of a Designation for Emergency Medical Services at Department Stores, Proceedings of the 32nd DAAAM International Symposium, pp.0415-0422, B. Katalinic (Ed.), Published by DAAAM International, ISBN 978-3-902734-33-4, ISSN 1726-9679, Vienna, Austria

DOI: $10.2507 / 32$ nd.daaam.proceedings.061

\begin{abstract}
With the advancement of technology and the architecture of buildings, more and more shopping centres are emerging, which attract hundreds to thousands of visitors every day. It is never clear in advance when any of these visitors will be in health danger or encounter any extraordinary events. If a person's health or life is endangered, urgent pre-hospital care is provided by the emergency medical service in the Czech Republic. For a smooth course and the fastest possible arrival and performance of the service, it is also necessary to have sufficiently planned logistics and boarding points at these department stores. This article aims to design signs and routes for the emergency medical service at the department store, aiming to streamline and speed up the trip and provide urgent pre-hospital care. Experimental and modelling methods are used in this article.
\end{abstract}

Keywords: emergencies; emergency medical service; model; signs.

\section{Introduction}

Today, department stores appear in every major city, but gradually even in smaller ones. Hundreds to thousands of visitors of all ages pass through these houses every day. Each of these visitors may encounter an emergency, such as nausea, limb injury, or even pledge, which would require an emergency medical service to provide the patient with urgent pre-hospital care and transportation to a hospital facility.

The arrival and placement of an ambulance at department stores is the frequent accumulation of visitors in front of department stores. Often, these people interfere with the smooth or complete passage of the ambulance with paramedics to the department store entrance. It would be possible to treat the patient and transport him to the hospital facility quickly. It is not always possible to manipulate the patient, and, for this reason, the emergency medical service must be brought as close as possible to the affected patient.

This article aims to design signs that would guide and clearly define the boarding point for the emergency medical service. This signs would have the effect of speeding up the travel time and informing the visitors of the department store about the possible arrival of the emergency medical service. Similar signs are already applied, for example, during the evacuation, which is one of the essential tasks of population protection. 
Thanks to signs on the ground and warning elements, people can evacuate much faster as they follow a pre-set route. Thanks to the path marked in this way, there is a higher success rate of evacuation and thus more saved lives. The article "A virtual reality-based study of indoor fire evacuation after active or passive spatial exploration" by Lijun Cao, Jing Lin $\&$ Nan Li describes two evacuation methods. Passive and active, where a faster evacuation was achieved during passive with the help of created tags. The Šantovka department store was chosen for the experimental model. Signs will be created, and paths to individual entrances will be designed to make rescue work more efficient. [1], [3], [4]

\section{Design of signage of places for emergency medical service}

To design places for the emergency medical service in front of the department store, the Šantovka department store in Olomouc was chosen as an experimental model. It is a modern department store with one underground, one ground floor and two above-ground floors. Each floor has at least one entrance to the building, of which there are nine in total. For more detailed research, entrances from the underground floor and above-ground floors had to be excluded. The reason for excluding these entrances is to limit the precise height of vehicles to 2 meters at the entrances to underground car parks and 2.2 meters at the entrance to the roof car park.

Entrance on the first floor was excluded due to the need to leave the vehicle on the adjacent road at a distance of 200 meters from the entrance to the building. Furthermore, the emergency medical service would have to overcome the height difference of one floor over this bridge for pedestrians only. Four entrances on the ground floor were chosen as suitable places for the location of the proposed signage for the needs of the emergency medical service. For clarity, the individual entrances are numbered and marked with yellow arrows pointing to the building in Figure 1.

\section{- podlaží}

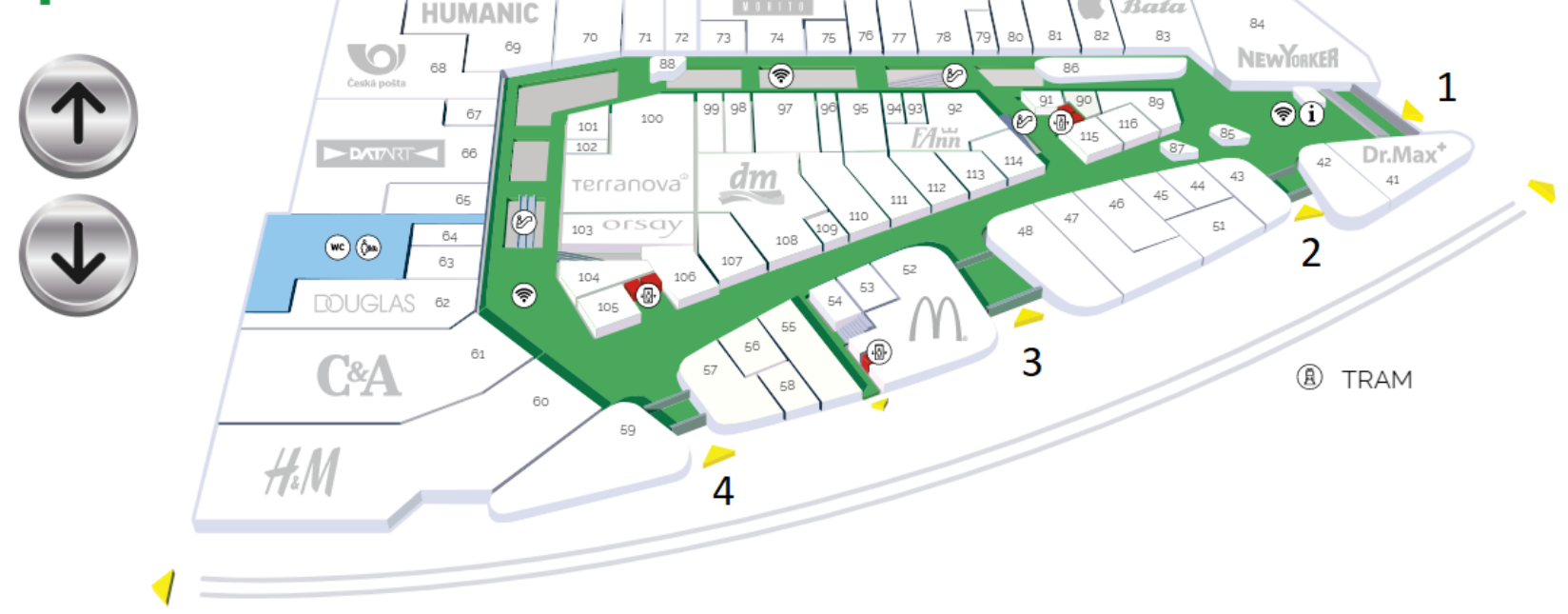

Fig. 1. Plan of the Šantovka department store [8]

A document issued by the Olomouc Region entitled "Plan for the coverage of the territory of the Olomouc Region by exit bases of the emergency medical service" divides the territory of the Olomouc Region into five territorial departments. These are the territorial departments of Jeseník, Šumperk, Přerov, Prostějov and Olomouc. There are six exit bases of the emergency medical service in the Olomouc Territorial Department, and three of these six bases are located in the city of Olomouc itself. Two are located on Hněvotínská Street, the base of the air rescue service and ambulance and rendezvous cars. There is an emergency medical service and ambulance base on Aksamitova Street.

The dislocation of the mentioned exit bases is shown in Figure 2. Geographic information systems were used to create map data in which the access routes and the distribution of the emergency medical service are shown. These systems are made up of hardware, software, people and data. A number of software are offered for the creation of geographic information systems, either paid or free.

QGIS software was used to create maps, which allows the display of geographical data in layers that overlap each other. The map also shows all access routes from both exit bases of the emergency services of the Olomouc region to the place of intervention at the Šantovka department store. Other maps contain a more detailed mapping of the emergency service's access routes to the department store's entrances. [2], [5], [7] 


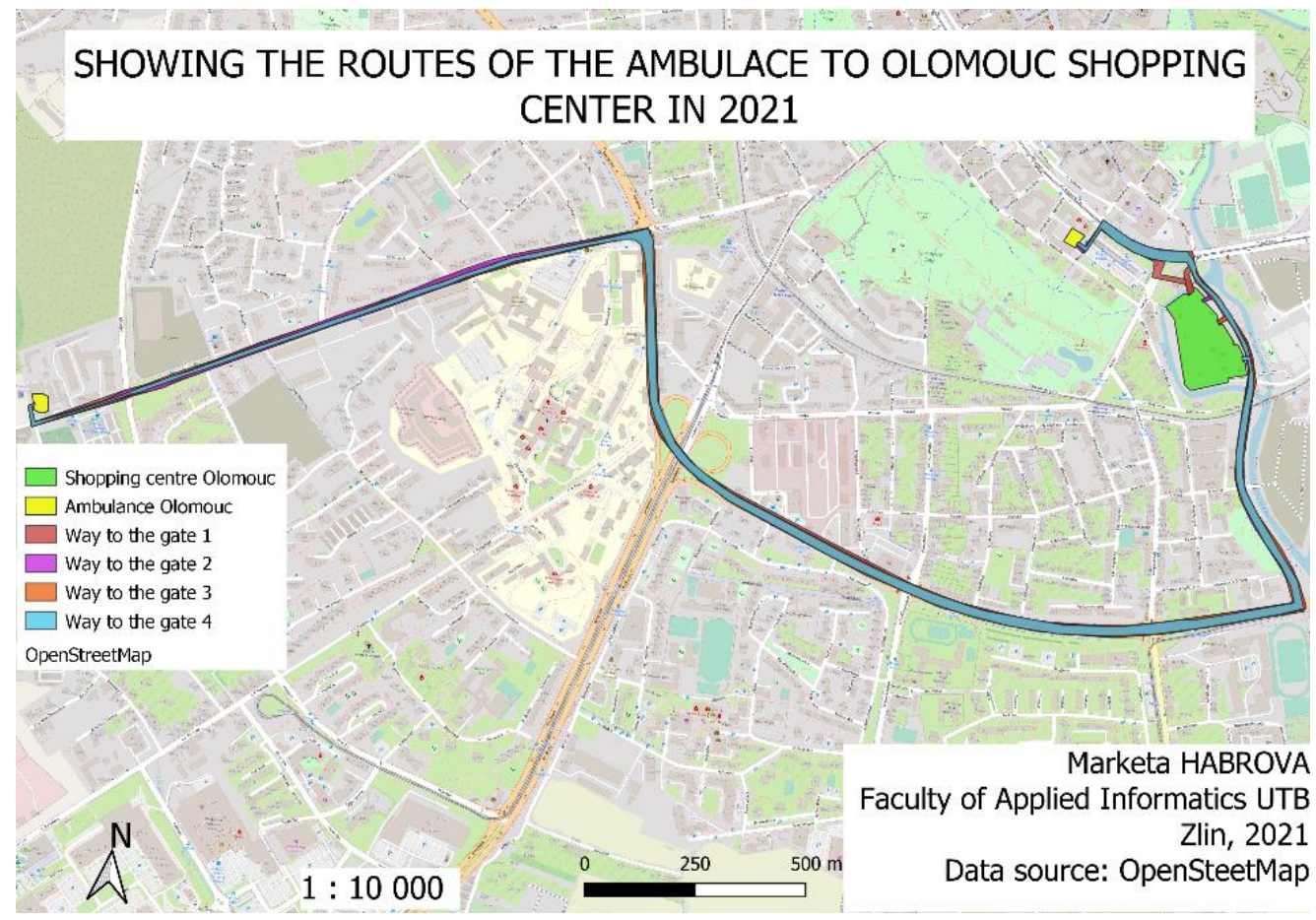

Fig. 2. Driveways of the emergency medical service to the department store Šantovka [6]

A yellow and black frame was chosen as a design for the emergency medical service at the Šantovka department store, which will alert passers-by to the possibility of an ambulance arriving. The text Place for emergency medical service is also given in this frame, and to preserve the visual of the business name, the logo of the Šantovka department store is also placed here.

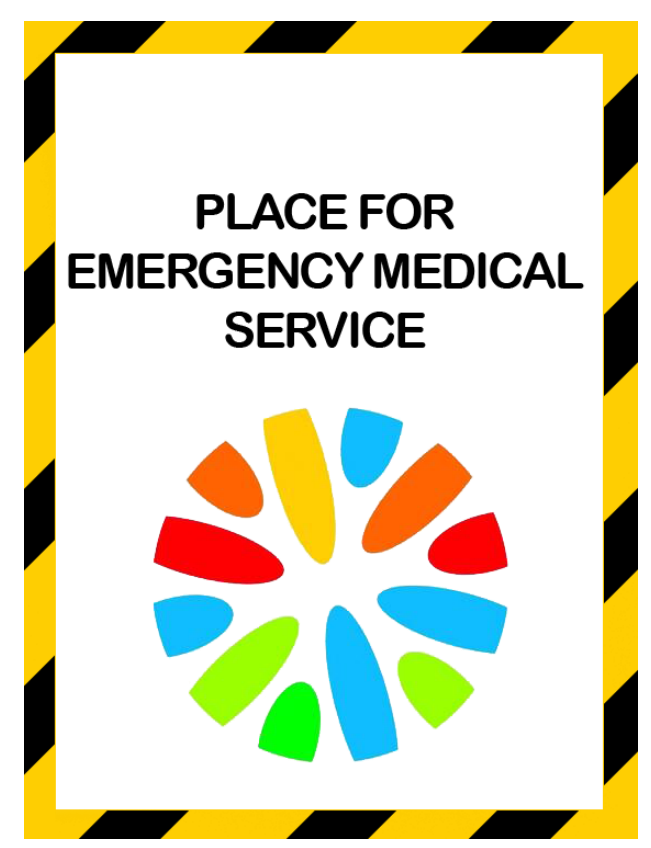

Fig. 3. Design of signs for the place of emergency medical services

\section{Entry No. 1}

Entrance number one to the Šantovka department store is located on the northern facade of the building. Signs indicating the place for the emergency medical vehicle is proposed on the left side 4 meters from the entrance with a front view of the building. This location was chosen because it is located near the electronic sliding door. The second part of the entrance consists of a revolving door which is not suitable for the entry of paramedics with their emergency equipment. Furthermore, there are bicycle stands on the right side, which makes the space unsuitable for placing signs. 


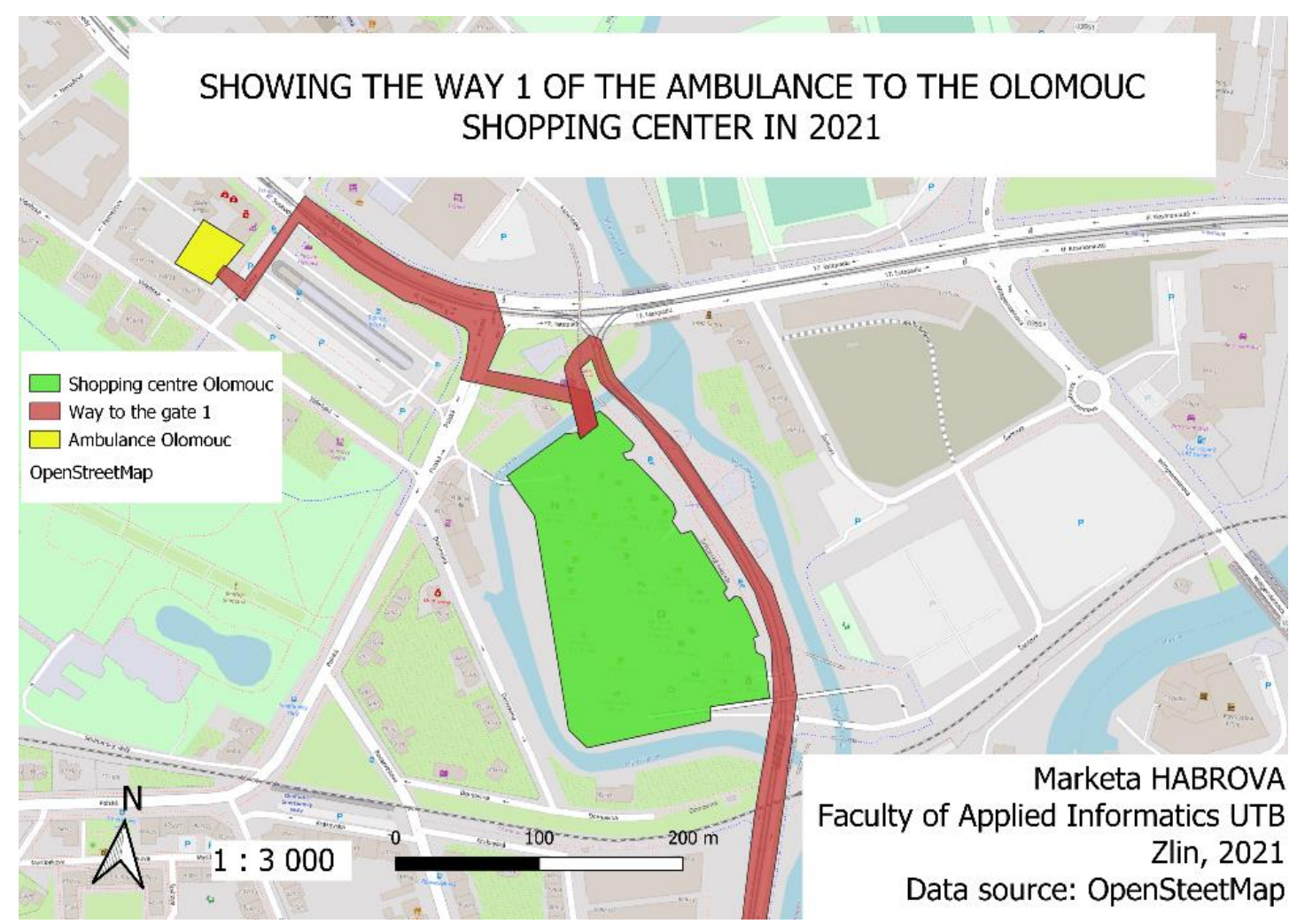

Fig. 4. The driveway of the emergency medical service to the first entry [6]

Figure 5 shows how an emergency medical service would be positioned if arrival at the first entrance were required. The car would have enough space for the performance, and a pre-marked place for their parking would alert visitors to a possible arrival.

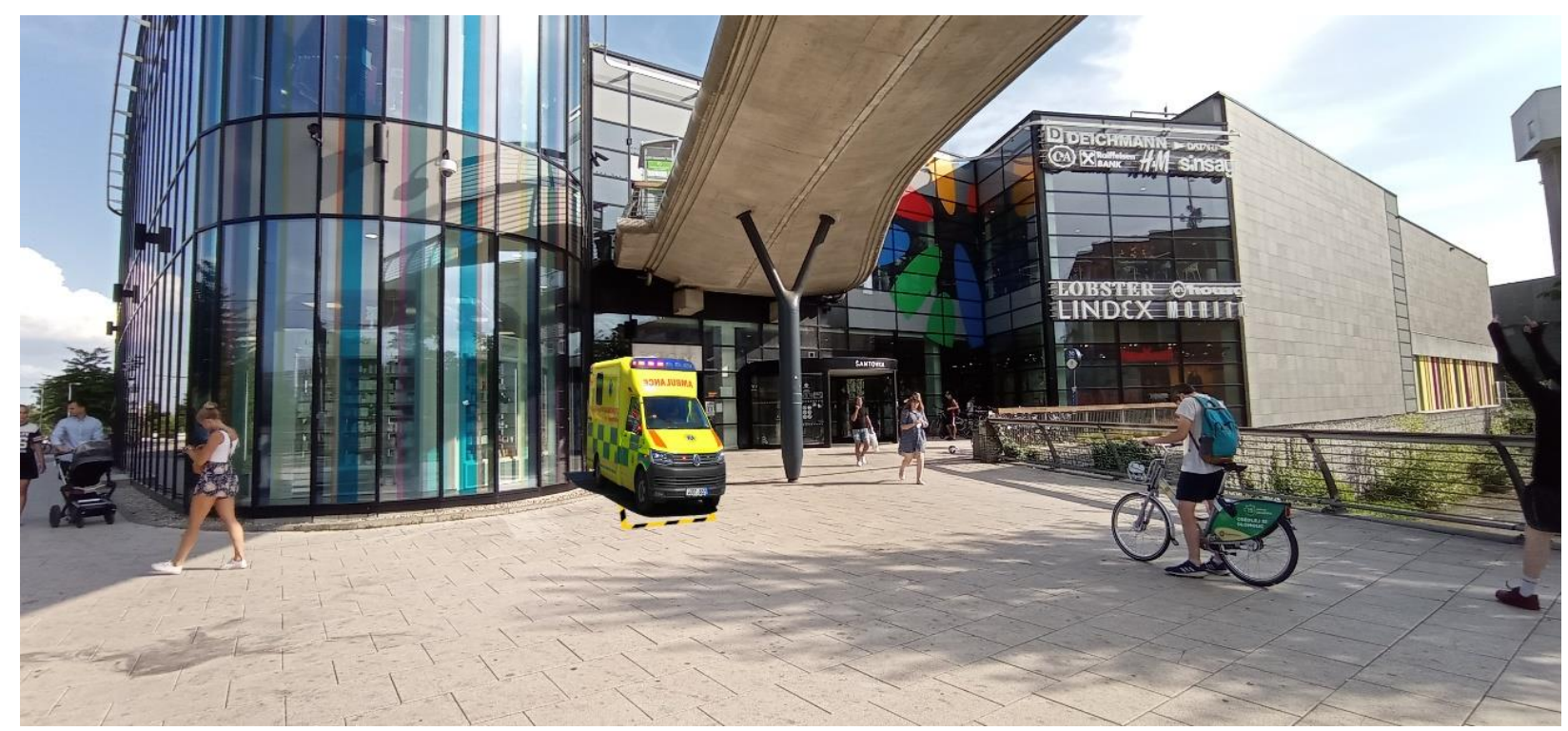

Fig. 5. Design of a stand for the emergency medical service at the first entrance

\section{Entry No. 2}

Entrance number two is oriented to the east, as well as entrances 3 and 4. It is equipped with one electronic sliding door. We propose to place the emergency medical sign on the left side 2 meters from the entrance from the front view of the building. In the vicinity of our proposed space, there is a basket with an ashtray, which accumulates standing people. We, therefore, recommend moving the basket to the right at least 5 meters from the front door, which would reduce the number of people standing outside the proposed area for the emergency medical service. 


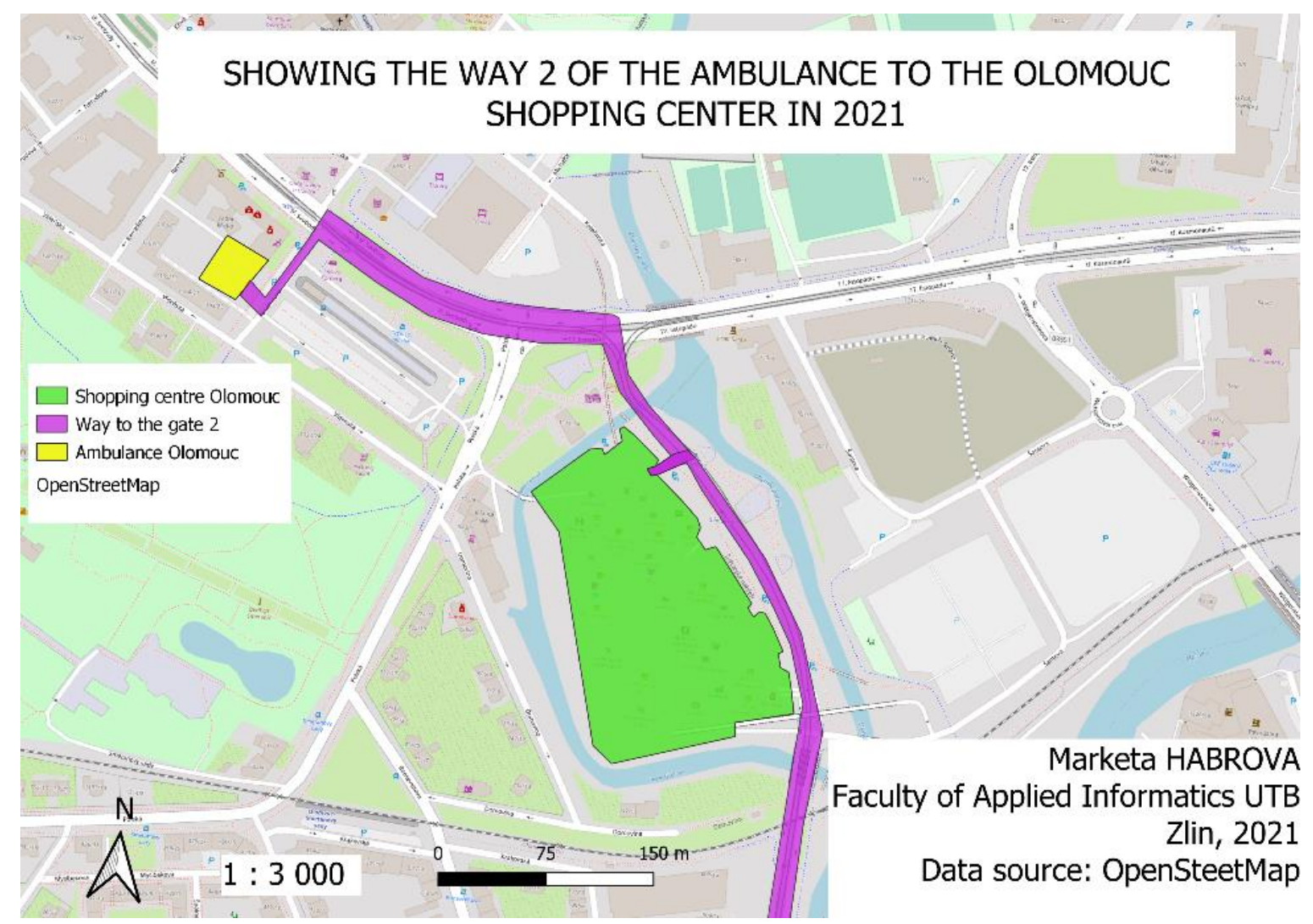

Fig. 6. The driveway of the emergency medical service to the second entry [6]

Figure 6 shows how an emergency medical service would be positioned if arrival at the second entrance were required. The car would have enough space for the performance, and a pre-marked place for their parking would alert visitors to a possible arrival.

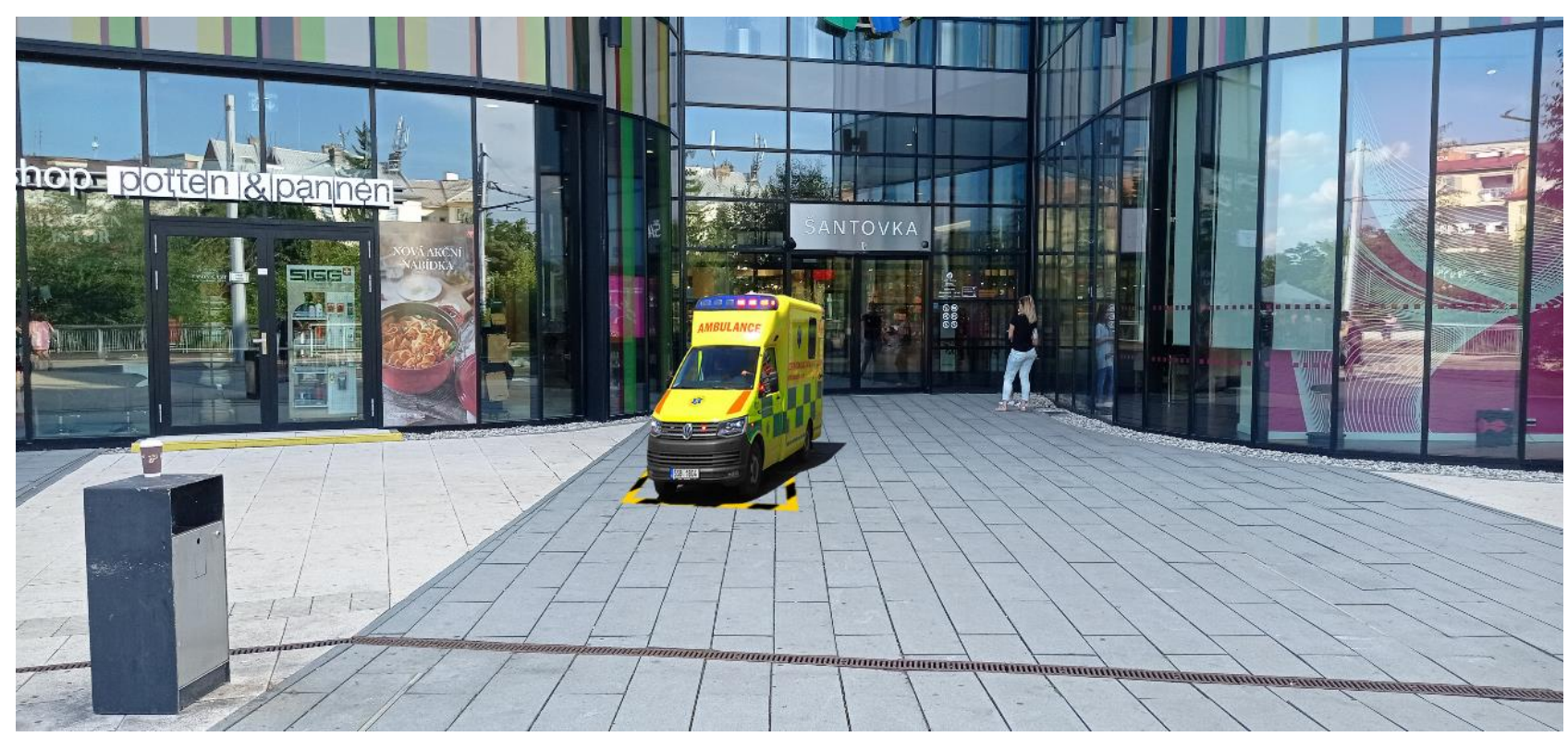

Fig. 7. Design of a stand for the emergency medical service at the second entrance

\section{Entry No. 3}

It is equipped with two electronic sliding doors. On the right side from the front view is a summer sitting area. Therefore, we suggest placing the signage to the left side of the entrance at 2-3 meters. It would be appropriate to consider relocating the basket again due to the accumulation of people. 


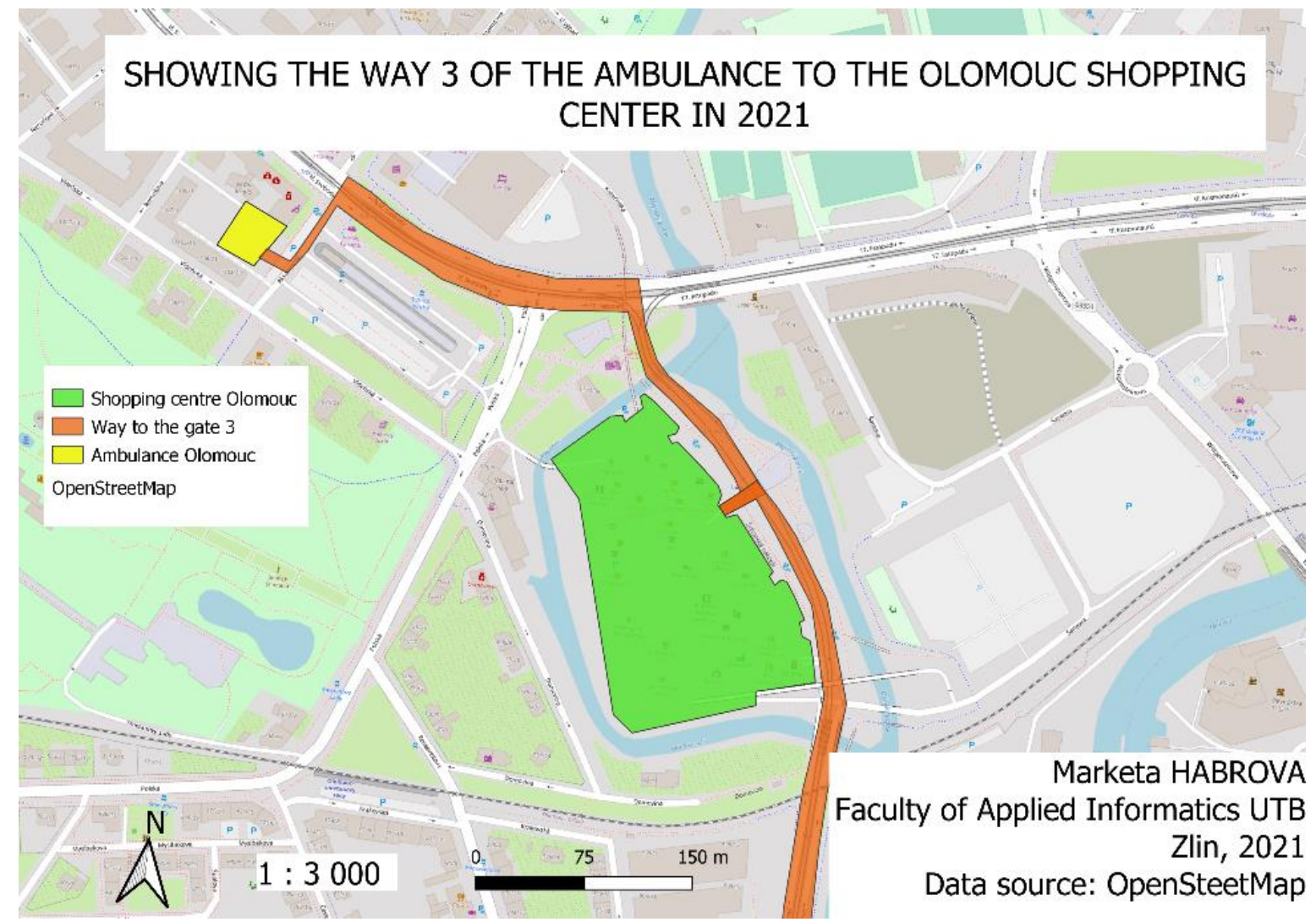

Fig. 8. The driveway of the emergency medical service to the third entry [6]

Figure 5 shows how an emergency medical service would be positioned if arrival at the third entrance were required. The car would have enough space for the performance, and a pre-marked place for their parking would alert visitors to a possible arrival.

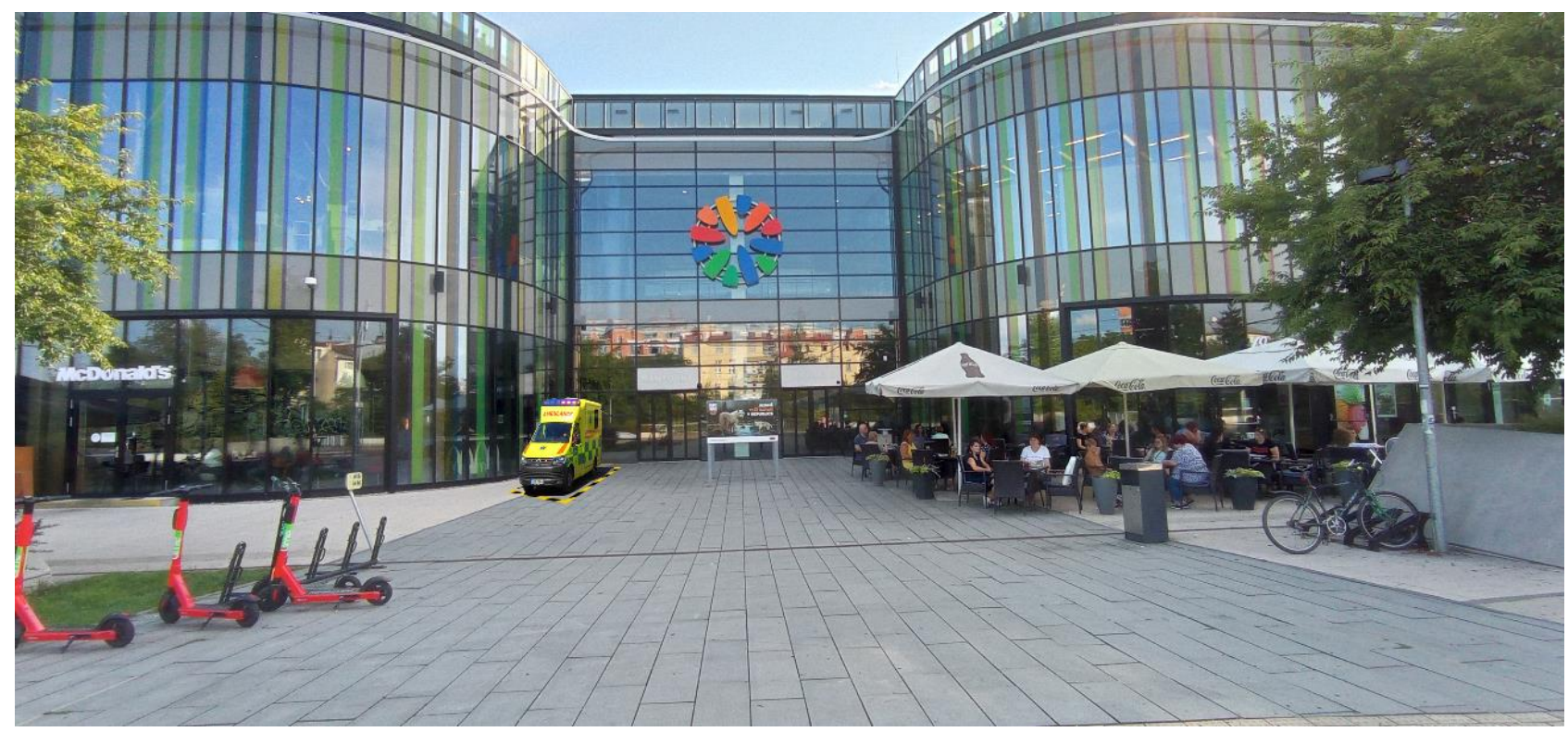

Fig. 9. Design of a stand for the emergency medical service at the third entrance

\section{Entry No. 4}

Entrance 4 is equipped with one sliding door. On the front view side, to the right of the door, there is a waste bin. We suggest placing the signs and the left side of the entrance about 5 meters from the gate. It is worth mentioning the bicycle stand, which could cause complications when entering and exiting the vehicle. 


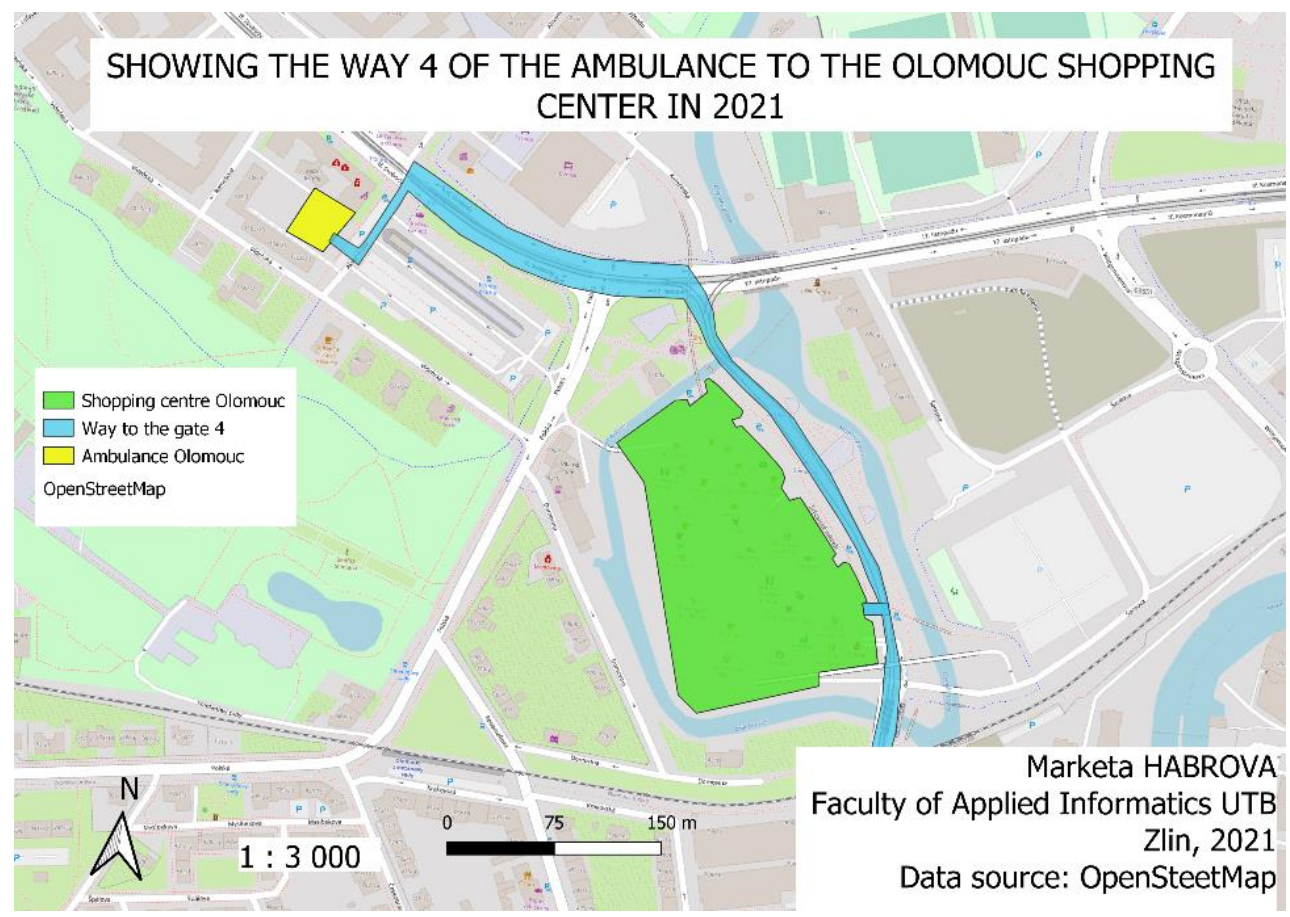

Fig. 10. The driveway of the emergency medical service to the fourth entry [6]

Figure 5 shows how an emergency medical service would be positioned if arrival at the fourth entrance were required. The car would have enough space for the performance, and a pre-marked place for their parking would alert visitors to a possible arrival.

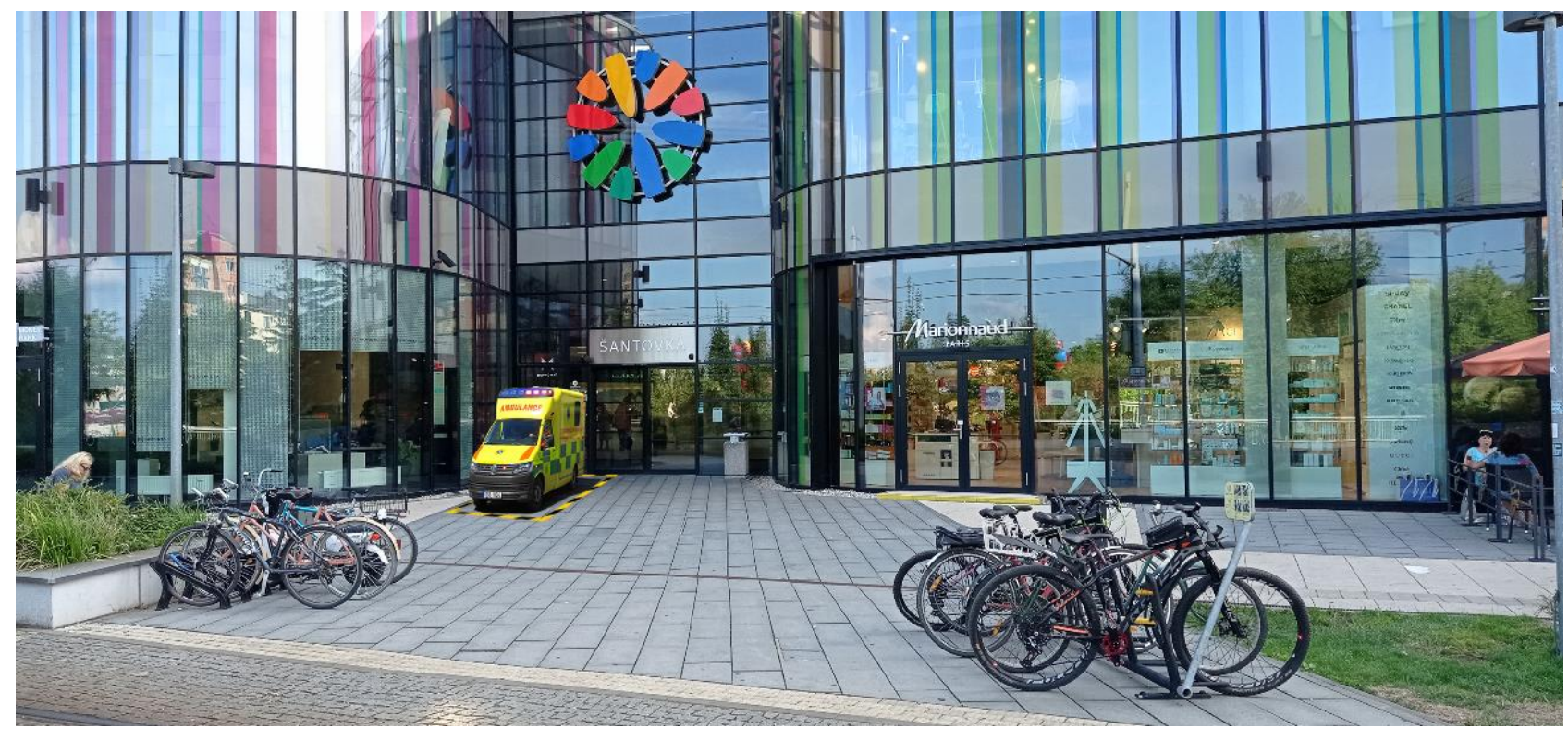

Fig. 11. Design of a stand for the emergency medical service at the fourth entrance

When deciding which input to use, it is necessary to consider which part of the department store the intervention of the emergency medical service will be performed. Decisive factors may be the distance from the entrance, the need to use an elevator, or people's cumulation at individual entries. Not all proposed measures need to be implemented. The financial and aesthetic aspects of the adjustments must be considered when making decisions.

However, one of the proposals that would allow a smoother passage of the emergency medical service to the department store is the relocation of bicycle stands. As can be seen in the department store pictures, bicycle stands are placed on both sides of almost all access roads. These bicycles can make it more difficult for an ambulance to pass, so it would be better to move these stands, for example, between benches along a department store. Another proposal that would reduce the cumulation of people in the proposed places for the emergency medical service is the removal of ashtrays. 


\section{Methods}

In the article, three scientific methods were used. The first was the explanation method, which explains the basic knowledge and objectives of the work. The second method is the modelling method, which was used to create map data in QGIS software. These map documents represent the routes of the emergency medical service to the individual entrances of the Šantovka department store and the general location of the emergency medical service in the city of Olomouc. The third method is the experiment method when the Šantovka department store was selected when the placement of signs for the emergency medical service was graphically designed. [9]

\section{Conclusion}

The article aimed to create a universal sign that would be placed at the main entrances to the department store because one of the problems of department stores is the boarding places for the emergency medical service or the generally integrated rescue system, where these places are not defined. The Šantovka department store in Olomouc was used as an experimental model. These signs are intended to indicate the possibility of the arrival of the emergency medical service. Therefore, people should not accumulate unnecessarily in these places and thus create more extensive groups of people. When an emergency medical service arrives, seconds can determine the patient's fate, and even these groups of people can delay paramedics during the procedure.

The article primarily describes the scientific problem and sets the article's goal, i.e., creating a proposal for signs places for emergency medical services at the department store. In this case, the Šantovka department store in Olomouc was used as an experimental pier. The next phase of the article was creating a signs design and creating map data in the QGIS software, which shows the emergency medical service routes to the department store's entrances. The last phase is the acknowledgments and references that were used to create this article. In further research, the authors aim to apply signs in a department store and perform a natural experiment, which would monitor whether visitors respect these signs and whether there is a decrease in the accumulation of people in these places.

\section{Acknowledgments}

This article was supported by an internal grant project of Tomas Bata University under the number IGA/FAI/2021/003 and an internal grant project of Tomas Bata University under the number IGA/FaME/2021/002.

\section{References}

[1] Coppola, Damon P. Introduction to international disaster management. Fourth edition. Amsterdam: Elsevier, [2021]. ISBN 978-0-12-817368-8.

[2] GIS Today. ESRI [online]. [cit. 2020-8-4]. Dostupné z: https://www.esri.com/en-us/what-is-gis/history-of-gis

[3] Haddow, George D., Jane A. Bullock a Damon P. Coppola. Introduction to emergency management. Amsterdam: Elsevier, [2021]. ISBN 978-0-12-817139-4.

[4] Lijun Cao, Jing Lin, Nan Li, A virtual reality based study of indoor fire evacuation after active or passive spatial exploration, Computers in Human Behavior, Volume 90, 2019, Pages 37-45, ISSN 0747-5632, https://doi.org/10.1016/j.chb.2018.08.041.

[5] Miklín, J., Dušek, R., Krtička, K., \& Kaláb, O. (2018). Tvorba map. Ostrava: OSU

[6] Open Street Map [online]. Available from: https://www.openstreetmap.org/\#map=15/49.3303/17.5290\&layers=H

[7] Plán pokrytí území Olomouckého kraje výjezdovými základnami zdravotnické záchranné služby. Olomouc, 2021. Dostupné také z: https://www.zzsol.cz/download/ZZS-OK_mapa-pokryti-olomouckeho-kraje_1.7.2021.pdf

[8] Šantovka [online]. Olomouc: Galerie Šantovka, 2019. Dostupné z: https://www.galeriesantovka.cz/obchody/mapacentra/

[9] Závěrečná práce - metodika, c2007-2013. Lorenc.info [online]. Praha: VŠE. From http://lorenc.info/zaverecneprace/metodika.htm 